\title{
The nexus between Indonesia's exchange rate and the world crude palm oil price
}

\author{
Cheng-Wen Lee, Andrian Dolfriandra Huruta
}

\begin{tabular}{|c|c|}
\hline \multicolumn{2}{|r|}{ A B S T R A C T } \\
\hline \multicolumn{2}{|c|}{$\begin{array}{l}\text { Objective: International trade plays a major role in increasing the output of each country. } \\
\text { Crude Palm Oil (CPO) is one of Indonesia's major export commodities. Facts show over } \\
\text { the past two decades, CPO has become a fast-growing product. However, there are ob- } \\
\text { stacles from one of Indonesia's CPO importers, namely the European Union. The aim of } \\
\text { this study is to explore the nexus between the exchange rate and the world price of CPOs. }\end{array}$} \\
\hline \multicolumn{2}{|c|}{$\begin{array}{l}\text { Research Design \& Methods: This study uses both the exchange rate of Indonesia and } \\
\text { the price data of the world CPO from } 1981-2017 \text { as secondary. Granger Causality was } \\
\text { used to explain the nexus between the exchange rate and the world price of CPOs. }\end{array}$} \\
\hline \multicolumn{2}{|c|}{$\begin{array}{l}\text { Findings: The results of the Granger Causality showed there was no causality be- } \\
\text { tween the exchange rate and the price of the world CPO. The lack of causality be- } \\
\text { tween the two variables suggests the trade balance's position is stronger and able } \\
\text { to explain the exchange rate. }\end{array}$} \\
\hline \multicolumn{2}{|c|}{$\begin{array}{l}\text { Contribution \& Value Added: This study indicated that the IDR exchange rate is more } \\
\text { sensitive to trade balance rather than the world CPO price. Moreover, It is necessary to } \\
\text { refined palm oil products to increase the contribution of the non-oil sector in Indonesia. } \\
\text { In addition, the Indonesian government needs to be aware of the European Union's } \\
\text { raised barriers to world trade. It means that Indonesia can make a positive campaign } \\
\text { about the advantages of palm oil production. }\end{array}$} \\
\hline \multicolumn{2}{|r|}{ research paper } \\
\hline Keywords: & ge Rate; World \\
\hline \multicolumn{2}{|l|}{ JEL codes: } \\
\hline & \\
\hline
\end{tabular}

\section{Suggested citation:}

Lee, C.-W., \& Huruta, A.D. (2019). The nexus between Indonesia's exchange rate and the world crude palm oil price. International Entrepreneurship Review (previously published as International Entrepreneurship / Przedsiębiorczość Międzynarodowa), 5(3), 35-47. https://doi.org/10.15678/IER.2019.0503.03 


\section{INTRODUCTION}

Crude palm oil (CPO) is one of the oils with the highest production and consumption in the world (Aprina, 2014; Ashfahany \& Priyatna, 2015; Buyung, Syechalad, Masbar, \& Nasir, 2017). In Asia, Africa, and South America, the majority of crude palm oil is produced. Indonesia and Malaysia dominate the global production of crude palm oil (Indonesia Investments, 2017). These two countries contribute about 85 to $90 \%$ of the total global production of palm oil. It can be recalled that 2018 was the year when Indonesia's national crude palm oil production rose to 42 million tons, while Malaysia crude palm oil production as 19.5 million tons (The Star, 2019). As we know that China, the European Union, Africa, India, the Middle East, and Pakistan are historically the major markets for Indonesian crude palm oil (The Palm Scribe, 2019).

In addition, CPO is one of the major export products from the plantation industry in Indonesia. As a major resource, CPO can also contribute to Indonesia's overall gross domestic product from 1.5 percent to 2.5 percent (Indonesia Investments, 2017). CPO also accounts for $30 \%$ of the total export revenue generated by the non-oil sector in its contribution to export revenue (Ashfahany \& Priyatna, 2015). It can be understood that the export value is associated with the price of the CPO. World CPO price would impact other countries' markets for exports of CPOs. As the largest palm oil producer and exporter of palm oil, Indonesia must be able to make changes to the world CPO price level.

As a country with a floating exchange rate system, Indonesia hands over the determination of the IDR (Indonesian Rupiah) exchange rate to the market (e.g., demand and supply of IDR). Therefore, many factors can influence exchange rate movements and one of them is the condition of international trade. International trade will be represented by exports or imports. As one of Indonesia's export commodities, CPO will be an important part of international trade and will also have an impact on the IDR exchange rate as a transaction tool (Aprina, 2014). The previous study indicated that world CPO price will affect the exchange rate of a country (Amano \& Van Norden, 1998; Ashfahany \& Priyatna, 2015; Aziz \& Applanaidu, 2017; Buyung et al., 2017; Edwards, 1986; Huda \& Widodo, 2017; Iqbal, Hameed, \& Devi, 2012; Kohlscheen, Avalos, \& Schrimpf, 2016). Conversely, the previous study showed Granger Causality tests do not find any evidence that commodity prices Granger-cause exchange rates (Chen, Rogoff, \& Rossi, 2010). Furthermore, the exchange rate does not have causality with some commodities (Saiti, Ali, Abdullah, \& Sajilan, 2014). In addition, Chan, Tse, and Williams (2011) stated that commodity returns do not share with currency returns causal relationships. Commodity prices and exchange rates are closely linked, but within one day the lead-lag relationship disappears. Based on the above-mentioned arguments, we can see the fluctuation of the world CPO price from 1967-2017.

Based on the above-mentioned arguments, this study has identified the nexus between Indonesia's exchange rate and the world crude palm oil price. The time-series analysis is used to apply the model to various testing procedures such as stationary test, cointegration test, lag length test, and Granger Causality test. The observation period starts from 1981-2017, which includes the policy related to national private estate credit \& people's core-transmigration plantation, Indonesia's financial crisis in 1998, the global financial crisis in 2007-2008, and the non-tariff barriers imposed by the European Union since 2011 until the present. 
The rest of the article is arranged according to the following sections. In the next section, we present a literature review and theory development. Next, we present materials and methods. Then, we present findings of the analysis results. Afterwards, we discuss the findings and in the last section we provide a conclusion and as well as present the implications for government policy and future research.

\section{LITERATURE REVIEW}

Several studies were done related to the nexus between the exchange rate and crude palm oil price. Buyung et al. (2017) using Vector Autoregression (VAR) proved that world CPO prices (Rotterdam) affect the exchange rate of IDR/US\$ and world soybean oil prices which are CPO substitution items (Amano \& Van Norden, 1998; Aprina, 2014; Aziz \& Applanaidu, 2017; Bodart, Candelon, \& Carpantier, 2015; Cashin, Cespedes, \& Sahay, 2004; Edwards, 1986; Kiatmanaroch \& Sriboonchitta, 2014; Kohlscheen et al., 2016). The increase in the IDR exchange rate will affect the price of some commodities and affect the CPO export prices in Indonesia. However, Ashfahany and Priyatna (2015) using the Error Correction Model (ECM) proved a long-term negative and significant relationship from CPO prices to Indonesian (IDR) and Malaysian (RM) exchange rates. In addition, Zou, Zheng, and Li (2017) also proved commodity prices in Australia and New Zealand have the ability to predict future exchange rates.

In countries that adhere to the floating exchange rate system (e.g. Australia, Canada, New Zealand, South Africa, and Chile), the previous study was also conducted. The floating exchange rate shocks the country's commodity prices (Chen et al., 2010). Malaysia also experienced unusual things related to palm oil commodity prices and the exchange rate, according to Saiti et al. (2014). There was no lag-lead relationship between the 1990-2012 period that could affect one factor with another variable between the exchange rate and the palm oil price (Chan et al., 2011; Chen et al., 2010; Saiti et al., 2014). The findings of the wavelet cross-correlation study will explain it. The different levels did not demonstrate the causality between the exchange rate and the oil palm commodities price.

In this article, we refer to the Balassa-Samuelson model. The model of Balassa-Samuelson is important to explain the relationship between the exchange rate and a commodity's relative value. This model identifies important factors that explain the relationship between exchange rates and relative prices (e.g., productivity growth) (Asea \& Corden, 1994). Thus, prices have risen in the non-traded goods sector. So it has an indirect impact on a commodity's price. Nevertheless, when prices increase in the non-traded sector, they will not be responded directly to the consumer. The sticky cost and wage model works in this situation. Therefore, commodity prices will rise that can be exchanged and trigger exchange rate appreciation (Chan et al., 2011). An increase in the productivity of CPO, especially in Indonesia, will be able to increase the price of CPO itself. The CPO price that tends to rise will increase the IDR exchange rate as demand for the IDR will also rise (Cashin et al., 2004).

Shiozawa (2017) also stated that the distinction between tradable and non-tradable products is relevant in the arguments concerning the Balassa-Samuelson model. There are no intrinsic properties but the difference between tradable and non-tradable products. The cost of transportation that makes certain goods tradable and some non-tradable. Indeed, if the cost of transporting goods between countries is always above the minimum difference in the cost of production, then such a good is will not be traded. On 
the other hand, when the transportation costs (including transaction costs and tariffs) are minimal, there are small differences in price particularly the good that will be traded between countries. Therefore, when the cost of transportation falls to a small proportion of the original cost, most previously non-tradable goods become tradable and would be exchanged in turn (Shiozawa \& Fujimoto, 2018).

International trade will certainly be close to the activities of exports and imports. A nation can trade with another country if there are variations in the cost of production and relative prices in exporting the products of the country with other countries (Shiozawa, 2015). In addition, if the opportunity cost of the country is lower in producing goods and if vice versa, a country will export (Pugel, 2016). Primary goods or goods that are the main commodities in a country (such as CPO in Indonesia) will be emphasized for export. According to Kahn (1984), the price of a commodity can be formed from the intersection between aggregate demand and aggregate supply (long term and short term). Every country must have a reliable commodity. Mainstay commodities will be used to show the existence of countries in international trade. According to Delle Chiaie, Ferrara, and Giannone (2017), global commodity exchange and involving many parties requires strong institutions and regulations. This is necessary to maintain the price of each commodity traded on the international market. Many factors can influence the movement of the demand and supply side of a commodity. One factor that is capable of influencing commodity price is global factors (Delle Chiaie et al., 2017). Global factor in terms of global demand side is able to vary prices and is strongly related to current economic conditions. In addition, Arango-Thomas, Arias-Rodríguez, and Flórez (2008) stated real interest rates also play an important role and are able to influence commodity prices in a country.

Moreover, the real exchange rate is one country's relative price level against another country and is a marginal exchange rate shift. The exchange rate structure also varies from every country (Zuhroh \& Kaluge, 2007). There are two types of exchange systems, the floating exchange rate, and the fixed exchange rate. A floating exchange rate is a system of exchange rates that do not have any party's interference and its price is left entirely to the foreign money market. On the other hand, the exchange rate remains closely linked to internal party (state) interventions (Pugel, 2016). Various factors can also affect a country's currency exchange rate. Exchange rates can be influenced by internal monetary variables such as real interest rates and production differentials (Kakkar \& Yan, 2014; Pugel, 2016). However, Kakkar and Yan (2014) reported that exchange rates can also be affected by external factors such as real gold prices representing the shock state of the global economic system.

\section{MATERIAL AND METHODS}

Figure 1 showed fluctuations in world CPO prices always occur every year. However, it is more likely to increase (e.g., positive trends began to occur in the 1980s). This condition occurs because of policies to facilitate the production of CPO in the form of National Private Estate Credit (PBSN: Perkebunanan Besar Swasta Nasional) and the People's Core-Transmigration Plantation (PIR-Trans: Perkebunan Inti Rakyat-Transmigrasi). On the other hand, the IDR exchange rate against the US\$ tends to weaken or depreciate. In 1998 there was a very significant change in both variables due to the monetary crisis that hit Indonesia. After the monetary crisis, Indonesia faced a number of obstacles which finally suppressed demand for CPO exports from Indonesia. When there was an 
appreciation of the IDR exchange rate, the European Union (as an Indonesian CPO importer) suddenly issued non-tariff barriers (e.g., 2011 until present). The non-tariff barriers imposed by the European Union are noted in the EU Directive policy. The application of CPO standardization entering the European Union due to the issue of Indonesian CPO which is not environmentally friendly (Sally, 2016). Certainly, the phenomena will affect the decline in demand from CPO exports and the IDR, which will lead to a fall in CPO price. According to Edwards (1986), the changes in the price of an export commodity will have an important effect on the country's exchange rate.

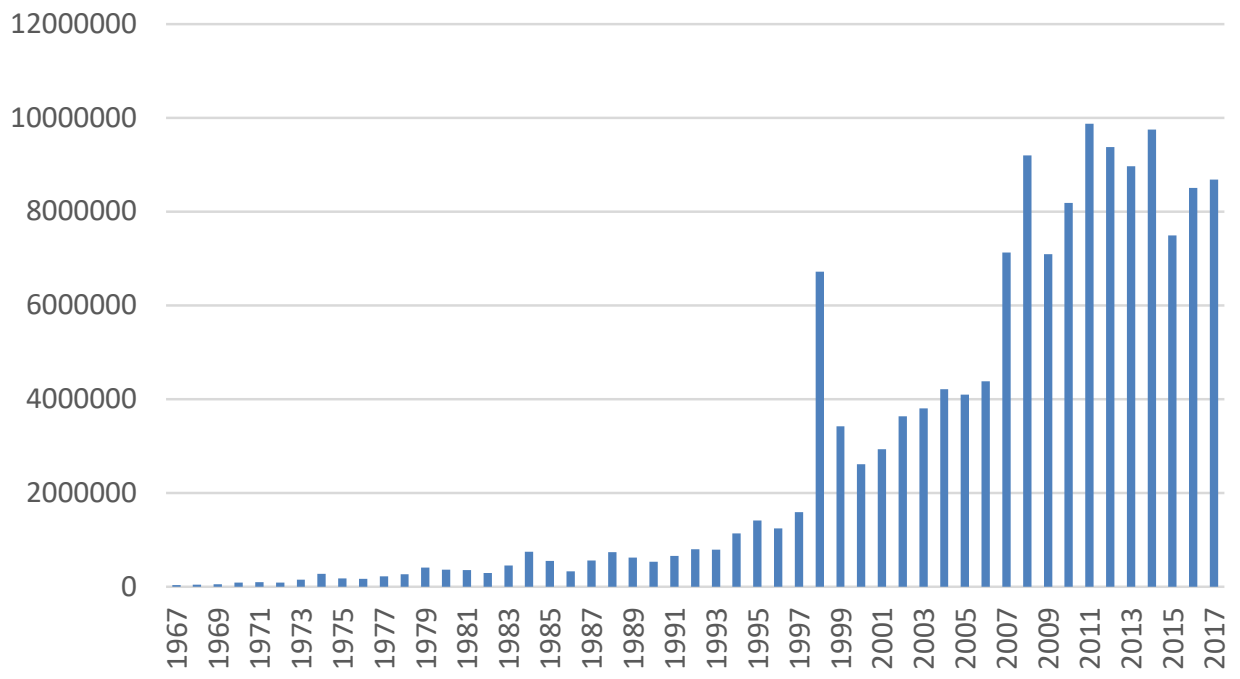

Figure 1. The World CPO Price from 1967-2017

Source: The World Bank (2018a).

\section{Time-Series Analysis}

Annual time-series data were obtained from the World Bank from 1981-2017. The two variables include the exchange rate of IDR to US\$ and the world CPO price. Statistical testing in this study begins with a stationarity test (Winarno, 2015).

where:

$$
Y_{t}=\alpha_{1}+\alpha_{2}+\delta \beta X_{t-1}+\delta \beta Y_{t-1}+e_{t}
$$

H0: $\delta=0$ (series has not stationary);

Ha: $\delta \neq 0$ (series has stationary).

In addition to the stationary test, the Cointegration test can be carried out through the Johansen Cointegration test (Rosadi, 2012).

$$
\begin{aligned}
& Y_{t}=\alpha_{1_{t}}+\delta X_{1_{t}}+e_{t} \\
& X_{t}=\alpha_{2_{t}}+\delta \mathrm{Y}_{1_{t}}+e_{t}
\end{aligned}
$$

Furthermore, a lag length test is needed to find the optimal lag (Lütkepohl, 2005). The modification of the sequential likelihood ratio (LR) experiment is done as follows. 
Starting from the maximum lag, use the $x^{2}$ statistics to test the hypothesis that the lag I coefficients are jointly zero.

$$
L R=(T-m)\left\{\log \left|\sum \in, l-1\right|-\log \left|\sum \in, l\right|\right\} \sim \chi^{2}\left(k^{2}\right)
$$

Equation 4 revealed that $m$ is the number of parameters per equation under the alternative. Remember that we use the small sample modification of Sims (1980) which uses $(T-m)$ instead of $T$.

While the Granger Causality test can be developed after the optimal lag length test is determined (Rosadi, 2012). The Granger Causality test is a statistical test of inference to determine if a one-time series is useful for forecasting. The Granger Causality test is such a technique to check the path of the nexus between the exchange rate of Indonesia and the world price of crude palm oil. Granger Causality's model can be seen in Equation 5 and 6 below.

$$
\begin{aligned}
& Y_{t}=\alpha_{1}+\sum_{i=1}^{m} \beta_{i} Y_{t-i}+\sum_{j=1}^{n} \gamma_{j} X_{t-j}+\mu_{t} \\
& X_{t}=\alpha_{2}+\sum_{i=1}^{p} \phi_{i} X_{t-i}+\sum_{j=1}^{q} \Psi_{j} Y_{t-j}+\eta_{t}
\end{aligned}
$$

There are four hypotheses to explain the causality between the IDR exchange rate and the world CPO value based on Models 5 and 6.

H1: Unidirectional Granger Causality from world CPO price to the IDR exchange rate $\sum_{j=1}^{n} \gamma_{j} \neq 0$ and $\sum_{j=1}^{q} \Psi_{j}=0$.

H2: Unidirectional Granger Causality from the IDR exchange rate to world CPO price $\sum_{j=1}^{n} \gamma_{j}=0$ and $\sum_{j=1}^{q} \Psi_{j} \neq 0$.

H3: Bidirectional Granger Causality from the IDR exchange rate to world CPO price and vice versa $\sum_{j=1}^{n} \gamma_{j} \neq 0$ and $\sum_{j=1}^{q} \Psi_{j} \neq 0$.

H4: Independence between IDR exchange rate and world CPO price $\sum_{j=1}^{n} \gamma_{j}=0$ and $\sum_{j=1}^{q} \Psi_{j}=0$.

The model was tested by F-tests particularly the probability values for $F$ statistics on lagged values of the exchange rate in Indonesia and with lagged values for such the world crude palm oil prices. While the calculations in this study were made with the software of the EViews 10 version.

\section{FINDINGS}

We provide results of analysis such as stationary testing, testing for cointegration, testing for the lag length, and causality of Granger. Table 1 below shows the stationary test results.

Table 1 showed the exchange rate series having the ADF-test statistic (-0.575422) smaller than the critical value (-2.943427). It indicated the series has no stationary. However, when the series is transformed into the first difference order, the value of the ADFtest statistic (-7.158927) becomes larger than the critical value of 2.945842). Therefore, it can be indicated that the series is stationary at the first difference order $(D(E R))$. Similarly, the world CPO price has an ADF-test statistic (-0.555129) lower than the critical value (2.943427). It indicated the series also have no stationary. However, when the series is transformed into the first difference order, the value of the ADF-test statistic (-7.151087) 
becomes larger than the critical value (-2.945842). Therefore, it can be indicated that the series is stationary at the first difference order $(D(C P O))$.

Table 1. Stationary test results

\begin{tabular}{|c|c|c|c|c|}
\hline Variable & $\alpha$ & ADF-test statistic & Critical value & Conclusion \\
\hline ER & \multirow{4}{*}{$5 \%$} & -0.575422 & -2.943427 & Series has no stationary \\
\hline $\mathrm{D}(\mathrm{ER})$ & & -7.158927 & -2.945842 & Series has stationary \\
\hline $\mathrm{CPO}$ & & -0.555129 & -2.943427 & Series has no stationary \\
\hline $\mathrm{D}(\mathrm{CPO})$ & & -7.151087 & -2.945842 & Series has stationary \\
\hline
\end{tabular}

Noted: ER implies the exchange rate; $D(E R)$ implies the exchange rate at the first difference order; CPO implies the world CPO price; $\mathrm{D}(\mathrm{CPO})$ implies the world CPO price at the first difference order.

Source: own study.

Table 2. Cointegration test results

\begin{tabular}{|c|c|c|c|}
\hline Hypothesized & Trace Statistic & $\mathbf{0 . 0 5}$ Critical value & Conclusion \\
\hline None & 27.25539 & 15.49471 & Cointegrated \\
\hline At Most 1 & 4.454253 & 3.841466 & Cointegrated \\
\hline
\end{tabular}

Source: own study.

Table 2 showed that a long-term relationship existed between the exchange rate and the price of the world CPO. Trace statistical value on hypothesis none as 27.25539 and hypothesis at most 1 as 4.454253 which is larger than the hypothesis critical value none (15.49471) and hypothesis at most 1 (3.841466).

Table 3. Lag Length test results

\begin{tabular}{|c|c|c|c|c|c|c|}
\hline Lag & LogL & LR & FPE & AIC & SC & HQ \\
\hline 0 & -616.2567 & NA & $2.07 \mathrm{e}+14$ & 38.64104 & 38.73265 & 38.67141 \\
\hline 1 & -604.6103 & $21.10919^{*}$ & $1.29 \mathrm{e}+14^{*}$ & $38.16314^{*}$ & $38.43797^{*}$ & $38.25424^{*}$ \\
\hline 2 & -603.3801 & 2.075961 & $1.54 \mathrm{e}+14$ & 38.33625 & 38.79430 & 38.48808 \\
\hline 3 & -602.3122 & 1.668485 & $1.86 \mathrm{e}+14$ & 38.51951 & 39.16077 & 38.73207 \\
\hline 4 & -601.6602 & 0.937269 & $2.33 \mathrm{e}+14$ & 38.72876 & 39.55324 & 39.00205 \\
\hline 5 & -600.5848 & 1.411447 & $2.88 \mathrm{e}+14$ & 38.91155 & 39.91925 & 39.24557 \\
\hline
\end{tabular}

* Indicates the optimal lag.

Source: own study.

Table 3 showed that the best lag to explain a variable's effect on the past of this variable and other endogenous variables is lag 1 . Therefore, to run the Granger Causality, lag 1 is sufficient.

Table 4. Granger Causality test results

\begin{tabular}{|l|c|c|c|}
\hline Null Hypothesis: & Obs & F-Statistic & Prob. \\
\hline $\mathrm{D}(\mathrm{ER})$ Does not Granger Cause D(CPO) & 36 & 0.39820 & $0.5324^{*}$ \\
\hline $\mathrm{D}(\mathrm{CPO})$ Does not Granger Cause D(ER) & & 0.37542 & $0.5443^{*}$ \\
\hline
\end{tabular}

* Accepted Null Hypothesis

Source: own study. 
Table 4 showed that the exchange rate $(D(E R))$ and the world CPO price $(D(C P O))$ are not causal. The results of Granger Causality are understood to have accepted the null hypothesis (independence between the exchange rate of IDR and the world CPO price). Acceptance of the null hypothesis is based on values of probability as 0.5324 and 0.5443 which are larger than critical values (5\%).

\section{DISCUSSION}

The results of Granger Causality test support hypothesis 4 that the IDR exchange rate and the world CPO price are independent (there was no causality between Indonesia's exchange rate and the world crude palm oil price). Our findings supported by Chen et al. (2010) and Chan et al. (2011) that there was no causality between exchange rate with commodity price. However, the commodity price fluctuations are typically more sensitive to short-term demand imbalance. There was similar research that works in Indonesia such as Saiti et al. (2014) that proved there was no causality between commodity price and exchange rate. However, they revealed the exchange rate is more sensitive to stock price (Pandya, 2016) rather than the commodity price. Still in Indonesia, Aprina (2014) argued that the CPO's global value directly and indirectly through the financial market influences the exchange rate. It can be understood that the higher price of CPOs results in an appreciation of the real rate of Rupiah. Therefore, the higher world price of CPO will increase domestic inflation, which will also increase the rate of Rupiah. In addition, there was a significant effect on the money supply (Nwosa, 2017; Omolade \& Mukolu, 2018) and with a positive sign of the domestic value of the CPO (Edwards, 1986). It means that the rising in domestic CPO prices would raise nominal money demand from the public. The current account improvement would increase the foreign exchange, which essentially increases the number of money supply in the country (Nwosa, 2017; Omolade \& Mukolu, 2018). The existing gap revealed that the exchange rate more sensitive to shortterm demand imbalance (Chan et al., 2011; Chen et al., 2010), the stock price (Saiti et al., 2014), and money supply (Aprina, 2014).

Further, our findings were not supported by the Balassa-Samuelson model (Shiozawa, 2017; Shiozawa \& Fujimoto, 2018). When the prices have risen in the nontraded goods sector, there was no impact on commodity prices to Indonesia's exchange rate. According to Ahmad (2014), although it has a long-term impact, the world CPO price has not been able to cause an exchange rate. It can be understood that there has been a larger influence on international trade from other factors compared to one of the key products of the world. The trade balance is one of the variables that the exchange rate can affect (Dogru, Isik, \& Sirakaya-Turk, 2019; Doukas \& Lifland, 1994; Ghosh, 2010; McKinnon, 1990; Zuhroh \& Kaluge, 2007).

The trade balance is an overview of the conditions of a country's export and import activities. The trade balance is determined by the difference in the price of the exports and imports of a nation (e.g., Indonesia) (Zuhroh \& Kaluge, 2007). It can be noted that exports from Indonesia outweigh imports and vice versa when the trade balance has a surplus. As Indonesia's trade balance rises, it reflects an increase in exports from Indonesia at the same time. The rise in Indonesian exports will boost the exchange rate in Indonesia. Empirically, the results of this study could not explain the direction of a definite relationship between the two variables (the exchange rate and the price of the world 
$\mathrm{CPO}$ ). Nonetheless, the strengthening of the conditions of the exchange rate can ultimately determine the status of Indonesia's trade balance (Zuhroh \& Kaluge, 2007).

Figure 2 showed the IDR exchange rate fluctuates with the trade balance trend. When the trade balance experienced a larger surplus, it was also followed by a stronger exchange rate (Zuhroh \& Kaluge, 2007). The situation tends to occur between 1981 to 2017. However, it is more clearly seen after the monetary crisis (1998). In 1998 Indonesia used a floating exchange rate system from previously using a fixed exchange rate system. Differences in trends only occurred from 1997 to 1998 during the monetary crisis (Aprina, 2014; Zuhroh \& Kaluge, 2007). The exchange rate weakened drastically. However, at the same time, the trade balance experienced a surplus. It can be understood that the prices of Indonesia's exported goods tend to be cheaper (Aprina, 2014). This condition is more supportive of how the IDR exchange rate actually works. The price of one commodity is not enough to affect Indonesia's exchange rate. However, the export and import positions in the aggregate are able to explain the condition of the IDR exchange rate and vice versa (Dogru et al., 2019; Doukas \& Lifland, 1994; Ghosh, 2010; McKinnon, 1990; Zuhroh \& Kaluge, 2007).

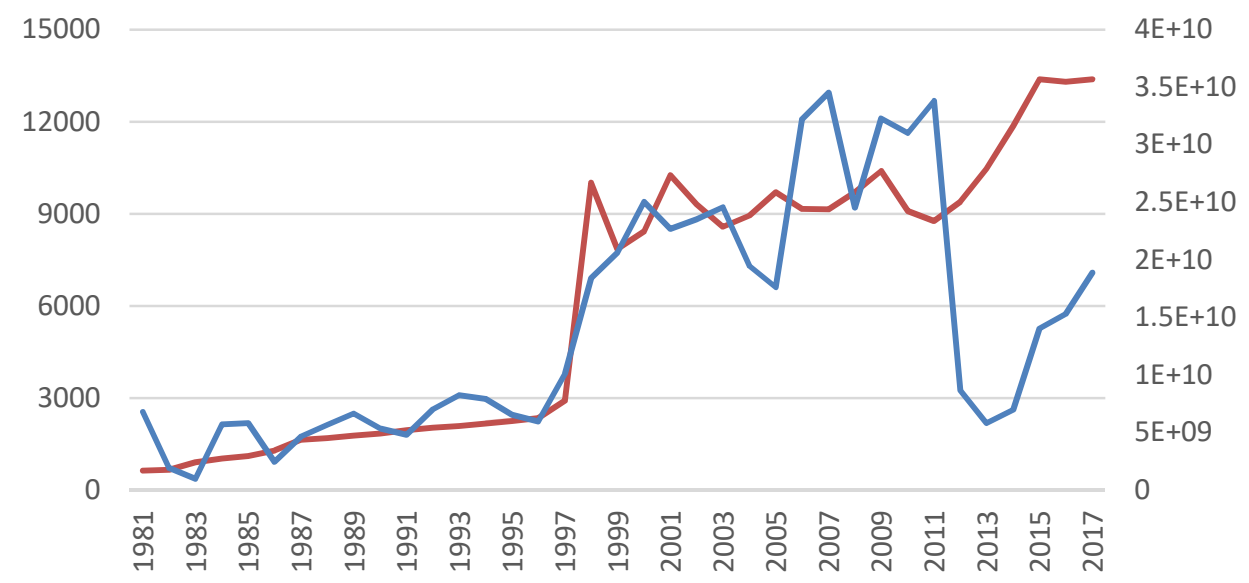

Figure 2. Exchange Rate dan Indonesia's Trade Balance from 1981-2017 Source: The World Bank (2018b).

\section{CONCLUSIONS}

Palm oil is one of the world's most widely produced and consumed oils. Indonesia is the largest producer and exporter of palm oil in the world, but it is also the largest greenhouse gas emitter after China and the United States. Nevertheless, palm oil is a major pillar of the economy of Indonesia. Based on the Granger Causality test we have proved that there is independence (no causality) between IDR exchange rate and the world CPO price. The absence of causality between the two variables indicates the influence of international trade (the trade balance) which is stronger and able to explain the exchange rate (Dogru et al., 2019; Doukas \& Lifland, 1994; Ghosh, 2010; McKinnon, 1990; Zuhroh \& Kaluge, 2007). Therefore, it is necessary to increase the value-added (Pandya, 2016) in Indonesia's processing of CPOs. It is aimed to increase the contribution of the non-oil 
sector. In addition, the Indonesian government needs to be aware of the European Union's raised barriers to world trade. In order words, Indonesia can make a positive campaign about the advantages of palm oil production.

Our findings become important for the Indonesian government as the world's largest palm oil producer. It also contributes to the literature on crude palm oil's development in Indonesia. We are reinforcing the previous research by Zuhroh and Kaluge (2007) related to the relationship between exchange rate and trade balance rather than Saiti et al. (2014) (the stock price) and Aprina (2014) (money supply).

Due to the current limitations, the Granger Causality was unable to clarify both the exchange rate and the world CPO price in the form of a specific relationship. Several models like Panel Data, Vector Autoregression (VAR) and Structural Vector Autoregression are appropriate to explain the causality between the exchange rate and the world CPO price. In addition, future research may consider the multivariate causality between trade balance, money supply, and stock price to explain the fluctuations in the exchange rate in Indonesia.

\section{REFERENCES}

Ahmad, N. (2014). Impact of Exchange Rate on Balance of Payment: An Investigation from Pakistan. Research Journal of Finance and Accounting, 5(13), 32-43. https://doi.org/10.4314/afrrev.v5i4.69260

Amano, R.A., \& Van Norden, S. (1998). Oil prices and the rise and fall of the US real exchange rate. Journal of International Money and Finance, 17(2), 299-316. https://doi.org/10.1016/S02615606(98)00004-7

Aprina, H. (2014). The Impact of Crude Palm Oil Price on Rupiah's Rate. Bulletin of Monetary, Economics and Banking, 16(4), 295-314.

Arango-Thomas, L.E., Arias-Rodríguez, F., \& Flórez, L.A. (2008). Trends, fluctuations, and determinants of commodity prices. Borradores de Economía; 521.

Asea, P.K., \& Corden, W.M. (1994). The Balassa-Samuelson Model: an Overview. Review of International Economics, 2(3), 191-200. https://doi.org/10.1111/j.1467-9396.1994.tb00040.x

Ashfahany, A.E., \& Priyatna, M.F. (2015). Analysis of World Crude Palm Oil Prices on the Real Exchange Rate: A Case Study of Indonesia and Malaysia. International Conference on Trends in Business and Economics, 19-23. Retrieved on November 11, 2019 from http://dx.doi.org/10.15242/ICEHM.ED0515510

Aziz, M.I.A., \& Applanaidu, S.-D. (2017). Effects of Palm Oil Price on Exchange Rate : A Case Study of Malaysia and Indonesia. Institutions and Economies, 9(4), 71-87. https://doi.org/10.1016/j.ijhydene.2017.03.147

Bodart, V., Candelon, B., \& Carpantier, J.F. (2015). Real exchanges rates, commodity prices and structural factors in developing countries. Journal of International Money and Finance, 51, 264284. https://doi.org/10.1016/j.jimonfin.2014.11.021

Buyung, Syechalad, N., Masbar, R., \& Nasir, M. (2017). The Analysis af Factors Affecting CPO Export Price. European Journal of Accounting Auditing and Finance Research, 5(7), 17-29.

Cashin, P., Cespedes, L.F., \& Sahay, R. (2004). Commodity currencies and the real exchange rate. Journal of Development Economics, 75(1), 239-268. https://doi.org/10.1016/j.econlet.2008.04.008

Chan, K., Tse, Y., \& Williams, M. (2011). The Relationship between Commodity Prices and Currency Exchange Rates. Commodity Prices and Markets, East Asia Seminar on Economics, 20(February), 47-71.

Chen, Y., Rogoff, K.S., \& Rossi, B. (2010). Can exchange rate forecast commodity prices? The Quarterly Journal of Economics, 125(3), 1145-1194. 
Delle Chiaie, S., Ferrara, L., \& Giannone, D. (2017). Common Factors of Commodity Prices. Banque de France Working Paper, 645(September). https://doi.org/10.2139/ssrn.3046410

Dogru, T., Isik, C., \& Sirakaya-Turk, E. (2019). The balance of trade and exchange rates: Theory and contemporary evidence from tourism. Tourism Management, 74, 12-23. https://doi.org/10.1016/j.tourman.2019.01.014

Doukas, J., \& Lifland, S. (1994). Exchange Rates and the Role of the Trade Balance Account. Managerial Finance, 20(5), 67-78. https://doi.org/10.1108/eb018476

Edwards, S. (1986). Commodity Export Prices and the Real Exchange Rate in Developing Countries: Coffee in Colombia. In L. Ahamed (Ed.), Economic Adjustment and Exchange Rates in Developing Countries (pp. 233-266). Retrieved on September 20, 2019 from http://www.nber.org/books/edwa86-1.

Ghosh, J. (2010). Exchange Rates and Trade Balance: Some Aspects of Recent Indian Experience. Economic And Political Weekly, 25(9), 441-445.

Huda, E.N., \& Widodo, A. (2017). Determinan Dan Stabilitas Ekspor Crude Palm Oil Indonesia. Ekonomi Dan Bisnis, 20(1), 47-68.

Indonesia Investments. (2017). Palm. Retrieved on September 20, 2019 from Indonesia Investments website: https://www.indonesia-investments.com/business/commodities/palm-oil/item166.

Iqbal, A., Hameed, I., \& Devi, K. (2012). Relationship between Exports and Economic Growth of Pakistan. European Journal of Social Sciences, 32(3), 453-460. https://doi.org/10.5539/ijbm.v8n21p108

Kahn, G.A. (1984). Theories of Price Determination. Federal Reserve Bank of Kansas City, (April).

Kakkar, V., \& Yan, I.K. (2014). Determinants of Real Exchange Rates: An Empirical Investigation. BOFIT Discussion Papers, 1. https://doi.org/10.2139/ssrn.2384500

Kiatmanaroch, T., \& Sriboonchitta, S. (2014). Relationship between Exchange Rates, Palm Oil Prices, and Crude Oil Prices: A Vine Copula Based GARCH Approach. Springer International Publishing Switzerland, 399-413. https://doi.org/10.1007/978-3-319-03395-2

Kohlscheen, E., Avalos, F.H., \& Schrimpf, A. (2016). When the Walk is not Random: Commodity Prices and Exchange Rates Monetary and Economic Department. 121-158.

Lütkepohl, H. (2005). New Introduction to Multiple Time Series Analysis. Retrieved on September 20, 2019 from http://www.afriheritage.org/TTT/2 New Introduction to Multiple Time Series Analysis.pdf.

McKinnon, R.I. (1990). The exchange rate and the trade balance - Insular versus open economies. Open Economies Review, 1, 17-37. https://doi.org/10.1007/BF01886174

Nwosa, P.I. (2017). External Reserves on Economic Growth in Nigeria. Journal of Entrepreneurship, Business and Economics, 5(2), 110-126.

Omolade, A., \& Mukolu, O.M. (2018). Monetary policy dynamics and the economic growth of the Sub Sahara Africa (SSA). Journal of Entrepreneurship, Business and Economics, 6(1), 36-58.

Pandya, B. (2016). Impact of Financial Leverage on Market Value Added: Empirical Evidence From India. Journal of Entrepreneurship, Business and Economics, 4(2), 40-58.

Pugel, T.A. (2016). International Economics Sixteenth Edition. McGraw-Hill Education.

Rosadi, D. (2012). Ekonometrika dan Analisis Runtun Waktu Terapan Dengan Eviews. Yogyakarta.

Saiti, B., Ali, A., Abdullah, N., \& Sajilan, S. (2014). Palm Oil Price, Exchange Rate, and Stock Market: A Wavelet Analysis on the Malaysian Market. Eurasian Journal of Economics and Finance, 2(1), 13-27.

Sally, N.U. (2016). Sengketa Minyak Sawit Antara Indonesia dan Uni Eropa. Dauliyah Journals, 1(1), 1-11. https://doi.org/10.1186/s40563-016-0062-8

Shiozawa, Y. (2015). International trade theory and exotic algebras. Evolutionary and Institutional Economics Review, 12(1), 177-212. https://doi.org/10.1007/s40844-015-0012-3 
Shiozawa, Y. (2017). The New Theory of International Values: An Overview. https://doi.org/10.1007/978-981-10-0191-8

Shiozawa, Y., \& Fujimoto, T. (2018). The Nature of International Competition Among Firms. In Industrial Competitiveness and Design Evolution (pp. 43-96). https://doi.org/10.1007/978-4431-55145-4_2

Sims, C.A. (1980). Macroeconomics and Reality. Journal of Econometric Society, 48(1), 1-48.

The Palm Scribe. (2019). 2018, A Gloomy Year for Indonesian Palm Oil Industry. Retrieved on November 18, 2019, from https://thepalmscribe.id/2018-a-gloomy-year-for-indonesian-palm-oil-industry/

The Star. (2019). Good weather expected to bolster Malaysia, Indonesia palm oil output. Retrieved on November 18, 2019 from https://www.thestar.com.my/business/business-news/2019/ 03/05/good-weather-expected-to-bolster-indonesia-malaysia-palm-output.

The World Bank. (2018a). Commodity Markets. Retrieved on November 18, 2019 from https://www.worldbank.org/en/research/commodity-markets\#2.

The World Bank. (2018b). Official exchange rate (LCU per US\$, period average) - Indonesia. Retrieved on November 18, 2019 from https://data.worldbank.org/indicator/PA.NUS.FCRF?locations=ID.

Winarno, W.W. (2015). Analisis Ekonometrika dan Statistika dengan Eviews (4th ed.). Yogyakarta: UPP STIM YKPN.

Zou, L., Zheng, B., \& Li, X. (2017). The Commodity Price and Exchange Rate Dynamics. Theoretical Economics Letters, 7(6), 1770-1793. https://doi.org/10.4236/tel.2017.76120

Zuhroh, I., \& Kaluge, D. (2007). Dampak Pertumbuhan Nilai Tukar Riil Terhadap Pertumbuhan Neraca Perdagangan Indonesia (Suatu Aplikasi Model Vector Autoregressive, VAR). Journal of Indonesian Applied Economics, 1(1), 59-73. 


\section{Authors}

The contribution share of authors is equal and amounted to $50 \%$ each of them.

\section{Cheng-Wen Lee}

Professor in International Business (Chung Yuan Christian University, Taiwan), Ph.D. in Commerce (Waseda University, Japan). Her research interest in the areas of environmental or technological innovation and transfer, multinational or global strategies (e.g., M \& A, strategic alliance, joint venture), and knowledge management.

Correspondence to: Prof. Cheng-Wen Lee, Ph.D., Department of International Business, Chung Yuan Christian University, 200 Chung Pei Road, Chung Li District, Taoyuan City, 32023, Taiwan, ROC, e-mail: chengwen@cycu.edu.tw

ORCID (1) http://orcid.org/0000-0002-4811-7000

\section{Andrian Dolfriandra Huruta}

Ph.D. student in the Ph.D. Program in Business (Chung Yuan Christian University, Taiwan). His research interest in the areas of macroeconomic policies, international trade, and applied econometrics.

Correspondence to: Andrian Dolfriandra Huruta., Ph.D. Program in Business, Chung Yuan Christian University, 200 Chung Pei Road, Chung Li District, Taoyuan City, 32023, Taiwan,ROC, e-mail: g10804610@cycu.edu.tw (the Corresponding Author)

ORCID (i) http://orcid.org/0000-0001-7676-5294

\section{Copyright and License}

() (1) $\Theta$

This article is published under the terms of the Creative Commons

Attribution - NoDerivs (CC BY-ND 4.0) License

http://creativecommons.org/licenses/by-nd/4.0/

Published by the Centre for Strategic and International Entrepreneurship - Krakow, Poland

Ministry of Science and Higher Education Republic of Poland
The journal is co-financed in the years $2019-2020$ by the Ministry of Science and Higher Education of the Republic of Poland in the framework of ministerial programme "Support for Scientific Journals" (WCN) on the basis of contract no. 238/WCN/2019/1 concluded on 15 August 2019. 
